\title{
Globalization and Cultural Conflict in Developing Countries: The South African Example
}

\author{
Philip O. Sijuwade \\ School of Urban and Public Affairs, University of Texas, Arlington Texas, USA \\ E-mail: sijuwade2000@yahoo.com
}

KEYWORDS Culture. Economic. Political. Racial. Religious. Ethnic

\begin{abstract}
ABSRACT Globalization requires more than physically linking the world. For it to continue apace, there must also be a set of shared cultural understanding. Part of the process of globalization is the need to develop a culture that, in some broad way, can transcend diverse economic, ethnic, political, racial, and religious background. Such a global culture will have to be one that either seeks to transcend normal affinities for one's own cultural group or undermine them. This process of producing a global culture will not occur without difficulty and conflict, especially for developing nations. The core values of western societies, especially, as embodied in a culture that places its primary concern on the rights of the individual are in conflict with the core values of many developing countries like South Africa. Many cultures in developing countries are based on a concept of protecting the livelihood of ethnic, racial, religious groups, or those who share a common language, not individuals. This conflict can be noted in different concepts of epistemology, morality, and social values. To reveal this conflict, I focus on the Republic Of South Africa. South Africa is a microcosm of this basic cultural conflict.
\end{abstract}

\section{INRODUCTION}

The global situation is in the process of rapid changes. The collapse of the Eastern Bloc, the end of the Cold War, and the disintegration of the Soviet Union dramatically changed relationships between nations. A "New World Order, "no longer based upon the antagonism of super powers, has begun to emerge. This New World Order significantly affects all humanity, especially, developing nations. They are no longer primarily viewed as pawns in a global chess match for world domination by super powers.

Driven by technological advances in communications and transportation, the process of globalization has also accelerated. These advances are inexorably linking all humanity in vast economic, communications, and transportation networks. Cultural ideas and images from one corner of the planet can be transmitted in an instant to another part of the planet by wireless and satellite technologies. The result is that cultures of different countries and diverse peoples are being brought into contact at rates unprecedented in human history.

Globalization requires more than physically linking the world. For it to continue apace there

Address for correspondence: P .O.Sijuwade,

1210 Mission Street, Duncanville, Texas,75137, USA.

E-mail: sijuwade2000@yahoo.com must also be a set of shared cultural understandings. Part of the process of globalization is the need to develop a culture that, in some broad way, can transcend diverse economic, ethnic, political, racial, and religious backgrounds. Such a global culture will have to be one that either seeks to transcend normal affinities for one's own cultural group or undermine them.

Philosopher Fukuyama (1992) termed these developments, the "end of history". For him, it meant that the culmination of human cultural development was at hand. The triumph of the West in the Cold war would inevitably lead to democracy as the only viable option for a political system, capitalism as the dominant economic system, a regime of individual rights to dominate inter-personal relations in the social arena, and governmental relations with its citizens. Fukuyama's prediction of the Westernization of the world presupposes that the New World Order will be based upon concepts at the heart of Western societies, especially, the United States.

This process of producing a global culture will not occur without difficulty and conflict, especially for developing nations. The core values of western societies, especially, as embodied in a culture that places its primary concern on the rights of the individual are in conflict with the core values of many developing countries. Many 
cultures in developing countries are based on a concept of protecting the livelihood of ethnic, racial, religious groups or those who share common language-not individuals.

This conflict can be noted in differing concepts of epistemology, morality, and social values, systems of ideas. To view individuals as members of cultural groups is to view the individual as a product of a system of beliefs. It is the cultural beliefs- not the individuals that has ontological supremacy. Respect is actually paid to a set of ideas, rather than to choices of individuals. To protect the rights of individuals is to protect the right of the individual to choose his or her own life path. One of the major impediments to self-determination is a historically developed culture that seeks to constrain the choices of individuals. Classifying and treating individuals by an ascribed trait or characteristic they possess, for which they are not in any way responsible, is contrary to the very purpose of human life that this cultural system of beliefs seek to advance. Therefore, protecting the rights of individuals involves a fundamentally different set of values from those that seek to protect the interest of cultural groups.

In this article, I discuss the structure of the basic conflict that group- oriented cultures in developing nations encounter when interacting with a culture that seeks to protect the rights of individuals. To reveal this conflict, I focus on the Republic of South Africa, the Bantu- speaking black Africans and the white Afrikaners. Then, I discuss the world's premier culture for the protection of individual rights, U. S. society. Thus, the United States provides a laboratory example of how one society has resolved the conflict between respect for cultural tradition and the rights of individuals. Because of the military and economic might of the United States, this example takes on added importance. Finally, I contrast the two group-oriented cultures with U. S. secular individualism. Respect for the interest of cultural groups involves a fundamentally different orientation of humans to life itself from a culture that seeks to protect individual self- determination. This conflict is irreconcilable, because it involves contradictory views of the human situation, human life, and the purposes for which humans have been created. What is at stake in the process of globalization is the basic question about the very nature, goal, and purpose of humanity itself.

\section{THE SOUTH AFRICAN SITUATION}

South Africa is a microcosm of the process of globalization. South Africa contains a number of radically different cultural groups centered on ethnicity, language, race, or religion (Gruchy, 1995). Approximately 76. 3 percent of South Africa's population is black, 12.7 percent is white, 8. 5 percent is colored, and 2. 5 percent is Asian. The largest ethnic groups among the blacks are the Zulu, Xhosa, Sotho, Tswana, Tsonga, and Swazi. The whites can be sub-divided into Afrikaners and English descendants. The largest linguistic group in South Africa is Zulu, followed by Xhosa, Sotho, Afrikaans, and English. While Christianity is the major religion of the people in South Africa, affiliations are split among many different denominations. Of those who specify a religious orientation, over thirty-two percent are members of various Christian. independent African churches. These are churches that typically have a blend of Christianity and traditional African religions. The next largest dominations are the Dutch Reformed Church (DRC) (16.6 percent among three different sects), Roman Catholism (10.9 percent), Methodist (8. 4 percent), and Anglican (5. 4 percent). From the 1960s until the 1990s, South Africa was a major Cold War battlefield. Thus, its international relations were, in large part, structured around the perceived need to be a bulwark against communism in southern Africa. At the same time, South Africa pursued its own internal policy of apartheid. Except for the need to exploit the labor power of non-whites, the fundamental basis of apartheid was the division of people along racial and ethnic lines and their separate development. The end of the Cold War completely changed South Africa's international relations and also affected their internal policies. South Africa was suddenly thrust into the forefront of the process of globalization. In addition, the implementation of full democratic principles has also affected its domestic policies. South Africa now has to reverse its policy of separate racial and ethnic development in an effort to produce a rainbow nation that also protects individual rights. But, at the same time, South Africa must respect the interests of the different cultural groups within its borders. Thus, the global task inherent in the bringing together of people from different cultural groups is replicated on a national level in South Africa. 


\section{A. South African Constitutional Provisions that Protect the Interests of Cultural Groups and Individual Rights}

There are provisions in the South African Constitution that expressly preserve the interest of cultural groups, protect individual rights, and mediate the conflict between individual rights and cultural affiliation. South Africa has eleven official languages and places upon the State the affirmative obligation to promote the status of the indigenous languages and to take practical and positive measures to elevate their status and advance their use. Section 29 of the Constitution provides that everyone has the right to receive an education in the language of his or her choice where such education is reasonably practical. For children, this right is one that can only be exercised by their parents or guardians who, through such education, will be able to increase the likelihood that the infant-when grown -is faithful to his or her parents' cultural groups. The Bill of Rights guarantees a number of individual rights, including; freedom of conscience, religion, and belief, freedom of expression, freedom to assemble peacefully; freedom of association; the ability to make political choices, and freedom to use the language and participate in the cultural life of their choice. Special mention must be made of Section 9 and 31 of the South African Constitution, because they expressly embody the conflict between promotion of cultural group interest and individual rights. Section 9 contains South Africa's equality provisions. It provides that everyone shall have the right to equal protection and benefit of the law and prohibits unfair discrimination on a number of diverse grounds including race, gender, sex, ethnic or social origin, color, and sexual orientation. Section 9 also provides that, to promote the achievement of equality, measures can be taken to advance categories of persons disadvantaged by unfair discrimination. Thus, on the one hand, a person is not to be treated as a member of a cultural group, but on the other hand, it is acceptable to treat a person as a member of a cultural group for the purpose of advancing groups who have been disadvantaged by unfair discrimination (Dreyfus et. al., 1983). Section 31 of the Constitution states that persons may not be denied the right to enjoy their culture, practice their religion, or maintain cultural, religion or linguistic associations. But these rights may not be exercised in a manner inconsistent with other provisions of the Bill of Rights. Thus, Section 31 seeks to protect the interest of the cultural group, but not at the expense of the rights of individuals.

From this quick look at the Constitution of South Africa, it is clear that the Constitution attempts to further both a legal regime of individual rights and protect the interest of cultural groups. But these two concerns are in fundamental tension. To analyze this tension, I first discuss the cultures of two groups, the Bantu-speaking black Africans and the white Afrikaners. In exploring these two cultures, I focus on the conception of the individual within each cultural system of beliefs.

\section{Traditional African Beliefs of the Bantu- Speaking Peoples}

Scholars have drawn numerous distinctions among the indigenous people of Southern Africa. A basic distinction is made between the Chosen (composed of the Khoikhoi and San people) and Bantu speakers. The Bantu speakers are divided into Nguni, Sotho-Tswana, Tsonga. and Venda groups. Further distinctions are made within the Nguni speakers. This section discusses the world view of the Bantu speaking South Africans, who represent over ninety-percent of the black South Africans. Anyone attempting to articulate the concept of traditional African beliefs among the Bantu-speaking people of South Africa quickly confronts a basic question: is there a set of such beliefs? It is generally recognized, however, that the traditional or ancestral religion of Bantuspeaking people in southern Africa can be inventoried. There are a significant number of uniform ideas that make up a common mental structure of beliefs of the Bantu and that distinguish their convictions from those of nonindigenous African peoples (Van Den Berghe, 1965). In viewing the relationship of the Bantu individual to his or her environment, it is best to distinguish between the connections of the individual to the homestead, from his or her connection to the larger community. The individual is socially constituted through webs of connection to others, living and dead, in a homestead and to a larger community. Individuals have obligations to the members of their homestead and community that must be discharged. In this section, I discuss the conceptual structure of the spirit world of 
traditional African beliefs; then, I show how the individual fits within the sphere of the homestead and the larger community that flows from this conception of the spiritual world.

\section{A. Conceptual Structure of the Spiritual World}

At the top of the order of things within traditional African beliefs is the High God. But the High God was primarily a reference point for the explanation of the origin of the human world. The High God was often referred to as the First Ancestor, the Giver of Life, and the Original Creator of all things. The High God is the ultimate divinity beyond time, space, or human control. Standing between the High God and human beings are the ancestors. Death does not lead a person through a dimensional door to an afterlife of heavenly bliss, hellish torment, redemptive purgatory, or oblivion. Instead, an element of the living human is viewed as surviving death to inhabit an afterlife. Usually, there is a connection between the High God and the Ancestral spirits. However, the High God is generally viewed as beyond human understanding or judgment. Prayers worship, or sacrifice are usually directed to the ancestors. Thus, Bantu religious beliefs concentrate on the role of ancestors (Chidester, 1992).

Though the ancestors are accorded power over the living, traditional African religion is chiefly a means of assisting the people in the acquisition of worldly goods. The chief concerns of religious practices are matters of interest gore the living such as health, wealth, and power, as well as social cohesion and social order. Ancestors can be either male or female; but male ancestors tend to play the dominant role. There is a lack of consensus regarding where the ancestors reside. Different places, such as underground, in the sky, or on the western horizon, are accepted as possible habitats. The one consistent feature is the ancestors' attachment to the living space of their descendants (Nyamiti, 1973; Magesa, 1997).

There are two different groupings of ancestors: those who are viewed primarily in terms of their relationship to an individual homestead and those who are viewed as the ancestors of the larger community. Except for tribal leaders, the recently departed are primarily concerned about matters in the homesteads they occupied while alive. As time passes and generations die away, ancestors go through a metamorphosis. Ancestors become more concerned with the interest of the community and less so with their former homesteads. Thus, over time, the influence of a given ancestor becomes more expansive and more diffuse.

The deceased do not automatically move into the realm of the ancestors. That status is conferred through a ritual process organized by the living. Typical burial rites are followed by a customary mourning period which is terminated by a second ritual. Those who do not have proper mortuary rituals performed for them could become rogue spirits that are capricious and indiscriminately harmful. Thus, performance of appropriate mortuary rituals by the suitable persons is a very important function of traditional African religions.

As superhuman entities, ancestors are capable of bestowing blessings as well as misfortune on their descendants. The ancestors are viewed as having the power to chastise their descendants for acts of disobedience. Ancestors, therefore, can cause illness or misfortune on the living. Punishment, however, is not administered so much to inflict harm. Rather, the punishment they inflict is intended to compel the living to uphold ritual or ethical obligations. Ancestors are generally referred to in the plural in the religious discourse and rituals. When they are referred to individually, it is because they are viewed as the as the cause of some illness, misfortune, or affliction. They are chastising their surviving descendants for some neglect of duties or breach of the moral order. The individual ancestor must be addressed separately in order to restore a state of harmony between the ancestor and the descendant (Gbadegesin, 1998). Ancestors and rogue spirits provide a partial explanation for illness and misfortune. There is another group of humans with special powers that are also implicated in the suffering of the living-witches and sorcerers. These living individuals employ superhuman powers to inflict harm. The superhuman powers that witches, who could be male or female, employ to harm people are derived from their inherently evil disposition. They could cause harm through evil psychic powers which are often supported by grotesque or wild animal spirits. In contrast, a sorcerer is not born with this power. Rather, his or her ability to cause harm to others is learned. A sorcerer is an ordinary person who learned the secrets of 
causing harm through powerful medicines and certain acts. One of the functions of ancestral spirits is to protect the living from witches and sorcerers.

\section{B. The Individual Homestead}

The home is the place where the social relations between the living and their ancestors are negotiated. The homestead is composed of the living and the ancestors who continue to show their interest in their surviving descendants. The primary function of the ancestors of the homestead is to supervise the lives of living descendants.

Within the sphere of the homestead, hierarchical relations predominate, with males being viewed as more powerful than females, adults more powerful than females, adults more powerful than children, and the old more powerful than the young. The individuals, as members of the family, also have duties to the ancestors of the family. The oldest adult male member of the homestead is typically seen as the ritual elder. Thus, he controls the homestead and can invoke the authority of the ancestors to support his decisions (Gbadegesin, 1998).

\section{The Larger Community}

In addition to the web of connections that the individual experiences within the homestead, there are also connections to the collection of homesteads that constitute the larger community. The community, which includes the ancestors, is considered to be an organic whole. The ancestors are considered to be the string in the web or net that holds the fabric together. The common reference by the typical African is the saying, "I am because we are: I exist because the community exists". As this reference suggests, the emphasis is placed upon solidarity of the community. The socialization of the individual includes the acceptance of obligations to the community. The individual is to understand him or herself as an integral part of the whole and play his or her appropriate role in the society. This is not to say that there are not situations where conflicts among individuals must be resolved. However, when the interest of the individual is pitted against important interests of the community, it is clear that the community takes precedence.

This sense of being part of a community carries with it an acculturated sense of concern for others because they are also members of the community. Thus, other individuals are not approached as agents for some particular function either to one's advantage or disadvantage. The chief, who is the apex of the community, is responsible for political authority, legal administration, and military defense. He also exercises religious authority for the purpose of strengthening the land and protecting the people. (Chidester, 1992). Like the homesteads, the chief will also call upon diviners or herbalists. But when he does it in his official capacity, he is doing it for the sake of the community.

\section{Afrikaner Culture}

In the years before the adoption of the Constitution in 1996, the primary conflict in South Africa was structured around race. This opposition should not, however, obscure the fact that whites were not a homogeneous, uniform, and monothic ruling class. The majority of the whites in South Africa came from two distinct European colonial settler populations. One groupthe Afrikaners-stems from the seventeenth century occupation of South Africa by Holland. The second is derived from Great Britain's control of South Africa, which started at the end of the eighteenth century. While the English descendants' first language comes from their native country, the Afrikaners speak Afrikaans, a language spoken only in South Africa. Afrikaans is a derivative of Dutch that became a standardized language in the nineteenth century. Most of the English descendants are either Anglican or Methodist. In contrast, most of the Afrikaners are members of one of three Dutch Reformed Movements. Prior to the adoption of majority rule, it was customary in South Africa to distinguish "White politics"-which was the struggle between the Afrikaner and the Englishfrom "non-White politics"-"the non-European struggle against White supremacy struggle. "The conflict between the two white groups can be traced back to 1795 when Britain occupied the Cape and thereby seized control from Holland. For the next 150 years, the two groups struggled for hegemony over South Africa, culminating with the seizure by the Afrikaners in 1948(Kiewiet, 1941).

\section{A. The Nationalist Party and Apartheid}

In 1948, the Afrikaner controlled Nationalist 
Party (NP) took control of the South African government. This takeover eliminated the need of the Afrikaners to compromise with the English when devising and implementing governmental policies. Even though there was a long history of discriminatory racial practices and policies before 1948, the elevation of the NP to dominance paved the way for the institution of apartheid policies. The concept that underlies apartheid is the division of the population into four racial groupsAsians (predominantly from India), blacks, colored, and whites. The four groups were to be separated physically and pursue their own development. Pursuant to these policies, a number of major pieces of legislation were passed by the South African Parliament. In 1949, Parliament passed the Prohibition of Mixed Marriages Act, followed a year later by the Immorality Act. These two acts made mixed marriages and sexual relations across racial lines illegal. In 1950, the Population Registration Act (which classifies people by race) was passed, and Group Area Act created racially exclusive zoning for residential areas. In 1953, after a court ruled that segregation of public facilities was not lawful, Parliament adopted the Reservation of Separate Amenities Act to legalize such separation. In 1955, a commission, chaired by F. R. Tomlinson produced a report, "The Socio-Economic Development of Bantu Areas", which became the basis for the Homeland policy. The Np pursued these political policies, in part, because of their religious convictions (Thompson, 1995).

b. Dutch Reformed Church in South Africa

The Christian worldview of the Afrikaner is enshrined in the Nederduitse Gere formeede Kerk (NGK), referred to in English as the Dutch Reformed Church. Its historical antecedents can be found in the sixteenth century. Calvin preached a stern theology, holding that God's laws must be rigorously obeyed, social and moral righteousness strictly pursued, and political life carefully regulated by religious concerns. Calvin explained salvation in terms of God's predestination. God, through his grace, determined in advance who would earn salvation and who would be condemned to hell. Calvin asserted that people can never know their fate with certainty. While this doctrine could and did lead some to despair, it also manifested an ironic twist. Those who, despite Calvin's assertion, believed that they were truly predetermined for salvation, acted with a sense of self-assurance and righteousness.

\section{Afrikaner Culture}

The Calvinist religious tradition manifested itself in a particularly racist way in South Africa. According to Weber (1958), the doctrine of predestination seems to lead to an anxiety about one's salvation. Thus, its adherents seek outward signs of their salvation. In places like Geneva and the United States these outward signs took the form of material prosperity. In South Africa, the most obvious and inevitable choice was skin color. The dark-skinned Africans became viewed as heathens with their darkness associated with sin and evil. In the Afrikaner reading of the Bible, God instituted divisions among humans. Particular solicitude is given to the story of God's destruction of the Tower of Babel. By such a division and confusion of the language, God revealed his will that people should live in separate cultural or ethnic units.

God created the Afrikaner nations for a special mission. Thus, the colonization by the Dutch that began in 1652 was not fortuitous, but parts of God's master plan that is unfolding in history. In leaving the Cape in 1835, the Afrikaners saw themselves as a reincarnation of the Old Testament Israelis fleeing from the British Pharaoh. God was on the side of the Afrikaners in their wars against the native African peoples. Their victories were divinely ordained.

Afrikaners are people chosen by God to help the blacks become self-supporting bearers of Christian civilization. The Federal Council of the Dutch reformed Church specified the special mission of the Afrikaner in 1935.

\section{Social Construction of the Individual}

The nation or ethnic group is the central form of human association and is an organic whole and not a collection of atomistic individuals. The ethnic group, and individuals within it, can be analogized to a human body. In society, different individuals perform different roles and functions just like, in the body, separate limbs and organs must work together for the body to function properly. Within Afrikaner culture, each person has his or her own task to perform for the harmonious existence of the group in its fulfillment of its mission from God.

The individual can only become fully developed within the ethnic group. Self-realization is only possible within one's group. It is through 
the service of the individual to his or her ethnic group pursues the divine mission set for it by God that individuals maximize their potential and obtain self-fulfillment. Further, the group's development and emergence result from divine forces which are independent of the will and wishes of humanity.

For Afrikaner culture, the subversion of the separate nations is viewed as an attack on the will of God. Afrikaner churches, historically, were segregated. Racial intermarriage was viewed as a rejection of the divine law of nationhood and as taking the first steps toward the restoration of a pre-Babel unity which God had condemned. This ban, however, does not seem to apply to the Afrikaners because they are made up of marriages between Dutch, French, Scottish. English and German colonists. In short, for the Afrikaner, while God Creates individuals, the Almighty Also creates nations. God's plan unfolds in history through nations. The characteristics as well as the mission of a given ethnic group are ordained and thus immutable.

\section{CULTURE OF INDIVIDUAL RIGHTS}

In this section, I examine a culture that seeks to protect the rights of individuals to show how that culture is in fundamental conflict with any other culture that seeks to advance the interest of an ascribed group. To protect the rights of individuals is to protect of the individual to choose his or her own life path. One of the major impediments to self-determination is historically developed cultures that seek to constrain the choices of individuals. Classifying and treating individuals by an ascribed trait or characteristic they possess, for which they are not in any way responsible, is contrary to the very purpose of human life that this cultural system of beliefs seeks to advance (Daniel, 1990). An example of such a culture is U. S. secular individualism. The United States is a land composed of immigrants, both voluntary and involuntary. From its beginning, the United States has had to resolve problems generated by differing cultural groups. Thus, the United States is an illustration of how one society has resolved the conflict between respect for cultural traditions and individual rights. With the development of modern techniques of communication and transportation, the United States has the ability to export its culture all over the world, including to South
Africa. For many developing nations, the process of globalization involves the conflict between their traditional cultures and U. S. secular individualist culture.

\section{A. Historical Development of U.S. Secular Individualism}

Important U. S. Values include democracy, materialism, consumerism, and empiricism-all of which may be at odds with important values in the traditional cultures of many developing countries. But, the best way to expose the conflict between the United States' dominant cultural values and those of developing societies is to contrast the concept of the individual, embedded in U. S. 's secular individualistic culture, with that of other belief systems.

Many people continue to think of the United States as a Christian nation. The United States was founded as a Christian nation and the Founding Founders were deeply religious. While dedicated to individual self-determination, the founders still paid homage to a higher power. The U. S. citizen of earlier times added to his belief in individuality and independence a reverse for something beyond the self. As Dworkin (1996) has pointed out, however, contemporary U. S. does not share the same willingness to a higher power that U. S. culture of the past did. The historical development of U. S. secular individualism, and its concomitant view of the individual, was the result of hundred of years of intellectual development. The origins of this culture are rooted in Judeo-Christian theology, which presupposes the existence of a God that created humans and endowed them with separate and unique, individual souls. The Christian origins of U.S. secular individualism perpetuated the fundamental belief in the existence of a unique and hidden self (the soul) for every individual but found that it could apply such a philosophy without paying homage to an almighty creator. In seventeenth-century England, John Locke developed a defense of individual rights for political and legal purposes that was not rooted in classical or biblical sources. The essence of Locke's philosophy was to view the rights of the individual as prior to society. In the state of nature, autonomous, self-determined, and free-willed individual pursue their own plans and purposes. These individuals choose to form a society because it will aid them in the pursuit of their 
desires. Thus, society "comes into existence only through the voluntary contract of individuals trying to maximize their own self-interest. "As a result, society and government are there to protect the natural rights of those individuals. Locke's theory makes it possible to begin thinking about society as a collection of individuals, without simultaneously acknowledging the subservience of these individuals to an omnipotent God. Locke's state of nature provides a way to think about people as individuals and not as subjects of a divine being. In the United States, thinking of individuals as ends in themselves provided the conceptual solution to a significant problem for a land of immigrants. Today, the United States is thought of as a place that has become the home of new immigrants from several countries. In its formative years, not only did the United States have to contend with many different European ethnic groups, but these groups also brought with them different religious traditions. The recent immigrants have brought with them Buddhism, Hinduism, Islam, and the religion of the Sikhs (Daniels, 1990). Immigration to the United States was the largest single voluntary migration in human history.

Between 1821 and 1924, total immigration to the United States exceeded thirty-three million

people. The character of U.S. immigration changed drastically around 1880 . A principally Protestant with immigrants from northern and western Europe, began to see a large influx of Catholic and Jewish immigrants from southern and eastern Europe. Between 1900 and 1930, the Catholic population doubled to twenty-four million. The massive increase in the number of Catholics was matched by the number of Jews. The Jewish population increased from 229,000 in 1887 to over 4, 228, 000 forty years later.

One of the primary motivations-or at least one of the concerns-driving the conception of U.S. society as a nation of individuals (especially as applied to white European men)was the desire to attenuate the ethnic and religious obligations and loyalties that were the result of historical traditions from religious obligations, but also to reduce the attachment of the individual to the "old country. "By reducing the sense of ethnic and religious identity, the possibility, and the possibility of destructive and violent ethnic and religious conflicts that so often flared up in parts of the world were largely avoided in the United States (Bellah, 1958).
Not long after the United States had become used to breaking down European immigrants groups, the thinking embedded in U. S. secular individualism was applied to resolve another long standing problem. In addition to voluntary immigration from Europe, the United States also had to contend with descendants of the sons and daughters of Africa. Africans were originally brought to the United States as slaves. While only 400, 000 Africans were actually brought to this country in chains, by 1950 , there were over fifteen million African-Americans living in the United States. Blacks were always an integral, though subordinated, part of U. S. society. Beginning in 1619, when the first Africans disembarked from the first slave ship to arrive in North America, blacks were treated as second class citizens in an almost unbroken chain of years until the 1950s.

In the 1950s, the United States began to dismantle its systems of racial apartheid by striking down long standing laws that separated and segregated black people from whites. Laws and customs that segregated blacks and whites at public parks, on buses, at municipal golf courses, public beaches, and public schools were ruled unconstitutional. U.S. secular individualism provided the solution for addressing the legacy of a society that dealt with African-Americans as members of a distinct racial group; that solution was to ignore everyone's race and all as individuals.

\section{B. Conceptual Structure of the Social World}

U. S. secular individualism sees the social world as a collection of "knowing individuals. "I refer to the concept of the individual embedded in U. S. secular individualism as a "knowing individual" in order to distinguish it from the concept of the individual in other systems of thought. The knowing individual is presumed to be self-directed, coherent, self-determining, freewilled, integrated, and rational. Knowing individuals are believed to be capable of obtaining a self- reflective position separate from all their aims and attachments. From this self-reflective position, they can assess and revise their aims and attachments. The capacity for self-reflection means that their attitudes, opinions, and beliefs can be understood as products of individual realization. Thus, knowing individuals are seen as selves that are capable of being free from any 
prior acculturation, tradition, obligation, or commitment. Within this cultural system of ideas, society comes into being as a result of free-willed, self-determined choices of knowing individuals. These individuals voluntarily decide to give up their isolation, from a society, and set up a government, because it is the best way to advance the pursuit of their self-determined goals and objectives. The benefit derived by knowing individuals from joining society is protection from the undue interference by others in the pursuit of their self-determined goals and objectives and enjoyment of their property. This benefit, made possible by the assumption of a burden by knowing individuals, assures a sphere for each knowing individual which is immune from interference by others. The assumed burden required that each knowing individual exercise self-restraint over his or her inclinations that would, if satisfied, directly interfere or create a substantial risk of others' ability to their goals and objectives. Thus, society and government exist to protect and support the choices of knowing individuals pursuing their goals and objectives. Government is there to ensure that knowing individuals have the freedom to pursue their self-determined goals and objectives without undue interference by others. The interest of knowing individuals is not to be sacrificed to the common good. Government is to be neutral with regard to competing conception of the good life. Government must not require the populace to be subservient to the wishes and dictates of an omnipotent God. Neither must the individual or the community pay homage to, give respect to, or court their ancestors for favors. Government should not seek to set up a State where knowing individuals are encouraged to view themselves as members of involuntary communities. Accepting and acting upon these concerns are matters of personal choice.

\section{Social Construction of Knowing Individual Identity within U. S. Secular Individualism}

The belief that knowing individuals are capable of obtaining a position from their aims and attachments requires the implicit recognition of a split in the personality of the knowing individual. There is a hidden essential self who exists outside of the empirical world and an empirical self that is presented to the outside world. This essential and hidden self is the "real" self. It is the self prior to all of the empirical characteristics of the knowing individual, including ethnicity, gender, race, religion, sexual orientation, or socioeconomic class. The ontological presupposition of this essential self is that it exists as a separate, unique, and distinct entity for every person. The essential self is viewed as the generator of the desire and predilections of the individual. The essential self is also capable of examining the empirical self and making judgments about how that self should be altered.

From this split in the personality comes the life-long quest of knowing individual. A knowing individual is thought of as engaged in a quest to discover his or her essential self, decipher its qualities and characteristics, and separate it from that which might obscure or alienate it. After comprehending his or her essential self, the knowing individual should seek to align the aspects of his or her interactions with the outside world so that interactions are in harmony with his or her essential self.

Contemporary U.S. society, perhaps more so than other society in human history, believes that the primary goal of life is for the knowing individual to engage in and then complete the task of harmonizing the essential self with those activities engaged in by it with the outside world. The presupposition of much of mainstream U.S. culture, and hence the journey of a lifetime that occupies knowing individuals on an emotional, psychological, and psychoanalytical level, is the search embodied in the attempt to comprehend and then to live in harmony with the unique and hidden part of whom a knowing individual truly is.

Knowing individuals should seek occupations or employment at jobs that allow their essential self to live unconstrained. Thus, to determine if one should become a banker, a doctor, a farmer, a lawyer. A priest, a school teacher, or a soldier, the knowing individual should consult his or her inner voice. Knowing individuals should seek out relationships with friends, but not because they have similar racial, ethnic, language, or religious backgrounds. Rather, they should seek to establish relationships with those whose essential selves are compatible with those who will assist them in obtaining their goals and objectives. For knowing individuals, the choice of a mate or spouse is one they make on their own. The knowing individuals should not choose 
someone because he or she feels under an involuntary obligation to choose someone who is of his or her same group, speaks the same language, practices the same religion, or is picked by his or her family. Knowing individuals should not wear clothes that reflect their social position or their ethnic group. Rather, the clothes they dress in should be ones in which they feel comfortable. Knowing individuals should even go so far to choose a religion that reflects the predilections of their essential selves.

Self-determination does not mean that the knowing individual can not consult others and take their advice into account when making important decisions. But, guidance received from community norms, spiritual advisors, religious edicts, or family members is merely advisory. The sole arbiter of these decisions is the knowing individual. The constant question about any decision on an important aspect of life for the knowing individual is:" Does this choice reflect who I really am?" U. S. secular individualism's commitment to self-determination is reflected in its maniacal dislike for treating knowing individuals according to a characteristic that they did not choose compromises their ability to be self-determining, and thereby, to structure their life so that their existence in the outer world is in harmony with their essential selves. The proper approach when dealing with such ascribed characteristics as ethnicity, gender, race, is to transcend those empirical characteristics in favor of dealing with the essential self. Transcending considerations of these empirical characteristics allows the knowing individual to escape being constrained by them. The implications for understanding which language a knowing individual speaks and what religious creed a knowing individual follows is dramatic. The knowing individual is viewed as viewed as choosing which language to use. Thus, speaking Afrikaans, Xhosa. Zulu or English is not indicative of involuntary group membership. Rather, it is viewed as the choice of knowing individuals who decide to align themselves with other knowing individuals in a voluntary association. Religious beliefs are viewed as products of choice rather than as constitutive of the knowing individual. Knowing individuals are not born or selected by the Almighty to be Methodist, Anglican, Zionist, Apostolic, Catholic, Hindu, Methodist, Protestant, or a follower of traditional African religious beliefs. Knowing individuals are conceptualized as choosing their particular religious orientation. The conception of society as a collection of knowing individuals requires that knowing individuals should not be compelled to view themselves as members of their racial, ethnic, religious, or language group. This concept, however, does not prevent knowing individuals from choosing to celebrate their racial, ethnic, religious, or linguistic membership as a salient part of their identity. Provision of the conceptual space for knowing individuals to choose a way of life is an essential feature of this cultural system of ideas, even if that way of life is one that requires the knowing individual to subordinate his or her individual interest to that of a racial group, ethnic group, the dictates of an omnipotent being, or even annihilation. As contradictory as it sounds, group affiliations which are not the product of individual choice are not to be eliminated, but are to become voluntary. In order to achieve this goal, traditions of beliefs, embodied by race, ethnic, religious, linguistic heritage must be converted into matters of preference that some individuals, who happen to share that membership trait, choose to follow and others choose to ignore.

\section{THE CONFLICT BETWEEN RESPECT FOR CULTURAL GROUPS AND INDIVIDUAL RIGHTS}

In contrast to promoting the interest of cultural groups is a system of beliefs that seeks to protect the rights of the individual. Protecting the rights individuals involves a fundamentally different orientation of humans to life itself. Protecting the interests of cultural groups requires viewing individuals as members of cultural groups, thereby rejecting the notion that the individual can be disassociated from his or her cultural group. The individual is conceptualized as a product of a system of beliefs. It is the cultural beliefs of the group-not the individual-that has ontological supremacy. The individual is to take his or her cue, regarding what to believe and how to act, from community standards norms. What the individual is and is supposed to be, is an actor in a cultural play performing a societal role. The individual is to play his or her designated part in the cultural drama. The suppression of his or her individual tastes, desires, and predilections is called for; in order for him or her to better play his or her part. Thus, respect is actually paid to a set of ideas, rather than to choices of individuals. 
In contrast to systems of beliefs that seek to protect the interest of the group, is one that protects the rights the rights of knowing individuals. U. S. secular individualism constitutes the knowing individual as one that is isolated and separate from other entities. There is a space, a gap, or a gulf that separates the knowing individual from all other knowing individual with whom he or she interacts. Knowing individuals are the rulers of their own empires and have the rights to choose their own life path. The goal of human life is the development and maturation of the individual personality brought about through its own creative experimentation with the unexplored and unknown possibilities of life. What is pursued is the attainment of harmony by the individual in adjusting his or her outside world to the predilections of his or her interior world. Among the major impediments to self-determination are historically developed cultures that seek to constrain the choices of individuals. Classifying and treating individuals by an ascribed trait or characteristic he or she possesses, which he or she is not in any way responsible for, is contrary to the very purpose of human life that this cultural system of beliefs seeks to advance.

\section{A. Conflict between Traditional African Beliefs of Bantu-Speaking South Africans and U.S. Secular Individualism.}

The construction of the individual within traditional African beliefs of the Bantu-speaking people is very different from the knowing individual of U. S. secular individualism. There is an irreconcilable difference in the interpretation of what is experienced, and therefore, a different understanding of what is to be valued.

For Bantu culture, the individual is connected to a homestead and a larger community that includes the living and other incorporeal spirits, through mystical non empirical connecting forces intricately woven into the fabric of the universe. Within traditional African beliefs, the unconnected individual of U. S. secular individualism does not exist. U. S. secular individualism does not deny the existence of incorporeal spirits or non empirical connecting forces. Rather, it implies that since their existence cannot be proven, whether such entities or forces are believed is a matter that each knowing individual must determine on his or her own. Opening up the conceptual space for the knowing individual to choose whether to believe in such entities and connecting forces requires the creation of doubt about their existence. It is through the conceptual space created by this doubt that U. S. secular individualism attenuates the presence of incorporeal beings (such as ancestors), and the power of non empirical connecting forces uniting the individual to the homestead and the community. This conceptual space of doubt is also the space that provides an opportunity for the liberation of the individual from the ascribed traditions of ancestor worship. Now the individual can choose not to believe in the world view that contains incorporeal beings and no empirical connecting forces.

Under U. S. secular individualism, value is placed on the unconnected self directing its own experience. With traditional African beliefs, the more connected to the community, to the ancestors, and to incorporeal spirits, the more valuable the experience and the individual having it. With U. S. secular individualism, the more choices that knowing individuals have, the greater the chance that they will be able to structure their lives in the way dictated by their essential self. Thus, the primary value is placed on the capacity to choose-not on connection to others.

In summary, for a former believer in the traditional African beliefs of Bantu-speaking people, manifesting a consciousness within U. S. secular individualism increases the value placed upon self-determination and the material world. This consciousness will come by a devaluation or loss of recognition of no empirical connecting forces and incorporeal spirits. The non empirical connecting forces will be cut and the presence of no empirical spirits, including ancestors, will become diffused and attenuated. The ancestors will be perceived as having departed and left to their own fate. Where the ancestors are going, the living can not follow, nor can they be of service to the living.

\section{B. Conflict between Afrikaner Culture and U.S. Secular Individualism}

As with Bantu-speaking culture, Afrikaner culture sees the individual in terms of his or her group. The individual was a member of a group created by the Almighty to implement God's plan that is unfolding throughout history. As with the existence of incorporeal spirits and no empirical 
connecting forces within traditional cultures of Bantu-speaking people, U. S. secular individualism does not deny the existence of an Almighty God with a plan that is unfolding in time. Rather, it asserts that it is up to the knowing individual to make a choice about whether to believe in the existence of an almighty with a divine plan, a conceptual space of doubt about the existence of such a God must be created. It is this doubt about the existence of the Almighty that attenuates the belief in Him. It also opens up the possibility for the knowing individual to become liberated from the mandates that are derived from a tradition of belief based upon the historical unfolding of the Almighty's divine plan. For a former believer in Afrikaner culture, manifesting a consciousness within U. S. secular individualism increases the value placed upon selfdetermination and the material world. What is lost in this revaluation of values is the sense of superiority that came to the Afrikaner from believing that he or she was a member of a cultural entity that was chosen by God for a special mission. An individual Afrikaner does not totally relinquish his or her position of superiority over the overwhelming majority of black Africans, but the basis of that superior position must be reconceptualized. The individual Afrikaner would no longer derive a sense of superiority from being a member of a group chosen by the Almighty to discharge a special mission. Rather, the sense of superiority is now derived from being in a stronger position to structure his or her outer world so that it accords with the predilections of the inner world. The sense of innocence for the oppression visited upon the black Africans by the Afrikaner will also be reconceptualized. Afrikaner culture understood Afrikaners to be God's chosen people pursuing a divine plan. Thus, they were not responsible for the subjugation and exploitation of the non-whites. Exploitation and subjugation were part of a divine and holy mission. As a knowing individual, as long as a given Afrikaner does not discriminate, then that individual is not responsible for the continued oppression of the black Africans.

\section{Perception of the Loss of Other Cultures by U.S. Secular Individualism}

I have presented U. S. secular individualism as a set of cultural beliefs with its own norms and expectations. Thus, it could be viewed as one culture competing against many others. But the conceptual problem for adherents of U.S. secular individualism is that this system of beliefs does not present itself as a cultural set of beliefs. Having a cultural set of beliefs requires the recognition that one is a member of a group. But, in a culture where the person is conceptualized as a knowing individual, one does not see oneself as a member of a group.

Built within this very system of thought is the inability of U. S. secular individualism to recognize itself as just another cultural system. It therefore appears to its adherents not as another system of beliefs, but as the reflection of reality or as the correct view of life from which all other beliefs can be judged in accordance. Thus, these cultural notions are lost by the mind of the secular individualist in such a way that they seem to have never existed. These individuals were in control even though they created incorporeal spirits, no empirical connect-ing forces and a Divine Being to act like they did not have control.

\section{CONCLUSION}

Respect for the interest of cultural groups involves a fundamentally different orientation of humans to life itself from that which seeks to protect individual self-determination. This tension is irreconcilable, because it involves contradictory views of the human situation, human life, and the purposes for which humans have been created. What is truly at stake in the process of globalization is the basic question about the purpose of humanity itself.

\section{REFERENCES}

Chidester, David: Religions of South Africa. Harper \& Row, New York (1992).

Bellah, Robert, Lipset, Martin and Lester, Paul: Habits of the Heart: Individualism and Commitment in American Life. Harvard University Press, Cambridge, Mass. (1985).

Daniels, Roger: Coming to America, a history of immigration and ethnicity in American life. American Journal of Sociology, 23: 132-150 (1990).

Dreyfus, Herbert, Redclift, Michael, Simon, Barry and Useem, David: Beyond Structuralism and Heremeneutics. Routledge \& Kegan Paul, London (1983).

Dworkin, Ronald: The Rise of the Imperial Self: America's Culture Wars in Augustinian Perspective. Houghton Mifflin, New York (1996).

De Kiewiet, Cornelius: A history of South Africa. Social \& Economics, 4: 27-36 (1941) 
Gbadegesin, Segun: Individuality, community and the moral order. In: Philosophy from Africa: A Text with Readings. P. Coetzee and J. Roux (Eds.). John Wiley, New York (1998).

Gruchy, John: Settler Christianity. In: Living Faiths in South Africa. M. Prozesky and J. Gruchy (Eds.). University of California Press, Berkeley (1995).

Magesa, Laurenti: African religion: The moral tradition of abundant life. In: Philosophy from Africa: A Text with Readings. P. Coetzee and J. Roux (Eds.). John Wiley, New York (1997).
Niebuhr, Reinhold: The Nature and Destiny of Man: A Christian Interpretation. New York; Doubleday Press, New York (1964).

Nyamiti, Charles: The Scope of African Theology. Abingdon, Nashville, Tenn (1973).

Van Den Berghe, Pierre: South Africa: A study in conflict. American Journal of Sociology, 67: 276-284 (1965).

Weber, Max: The Protestant Ethic and the Spirit of Capitalism. Scribner's, New York (1958). 